\title{
Early Life Ovalbumin Sensitization and Aerosol Challenge for the Induction of Allergic Airway Inflammation in a BALB/c Murine Model \\ Kyle T Mincham ${ }^{1}$, Naomi M Scott ${ }^{1}$, Jean-Francois Lauzon-Joset ${ }^{1}$, Jonatan Leffler ${ }^{1}$, Philip A Stumbles ${ }^{1,2,3}$, Patrick G Holt ${ }^{1}$ and Deborah H Strickland ${ }^{1}$, *
}

\author{
${ }^{1}$ Telethon Kids Institute, University of Western Australia, Nedlands, Western Australia, Australia; ${ }^{2}$ School \\ of Veterinary and Life Sciences, Murdoch University, Perth, Western Australia, Australia; ${ }^{3}$ School of \\ Paediatrics and Child Health, University of Western Australia, Subiaco, Western Australia, Australia \\ *For correspondence: Deb.Strickland@telethonkids.org.au
}

\begin{abstract}
[Abstract] The early life period represents a time of immunological plasticity whereby the functionally immature immune system is highly susceptible to environmental stimulation. Perennial aeroallergen and respiratory viral infection induced sporadic episodes of lung inflammation during this temporal window represent major risk factors for initiation of allergic asthmatic disease. Murine models are widely used as an investigative tool to examine the pathophysiology of allergic asthma; however, models in current usage typically do not encapsulate the early life period which represents the time of maximal risk for disease inception in humans. To address this issue, this protocol adapted an experimental animal model of disease for sensitization to ovalbumin during the immediate post-weaning period beginning at 21 days of age. By initially sensitizing mice during this early life post-weaning period, researchers can more closely align experimental allergic airway disease models with the human age group most at risk for asthma development.
\end{abstract}

Keywords: Asthma, Allergy, Airway inflammation, Ovalbumin, Sensitization, Early life

[Background] Allergic asthma is a highly heterogeneous and complex inflammatory disease of the airways, with current estimates indicating over 350 million individuals worldwide are affected (Masoli et al., 2004; Soriano et al., 2017). The classical hallmark features of the disease include elevated antigen-specific serum immunoglobulin E, CD4 ${ }^{+}$T-helper (Th) type 2-driven eosinophilic inflammation and reversible airways hyperresponsiveness to innocuous environmental antigens (Bousquet et al., 2000; Holgate, 2008).

Allergic asthma is recognized as a developmental disease with its inception now acknowledged to occur most commonly during the early stages of postnatal development. During this period, the inability of the functionally immature immune system to mount an efficient response to innocuous perennial aeroallergen exposure and respiratory viral infection leads to periods of exaggerated/dysregulated airways inflammation (Johnston et al., 1995; Holt et al., 2005; Jackson et al., 2016). This persistent inflammatory state within the airways can lead to loss of function and in concert with atopic sensitization during this time of immunological plasticity, promote the eventual onset of an established asthmatic phenotype during childhood (Holt et al., 2005; Jackson et al., 2016).

To elucidate the cellular and molecular mechanisms driving disease pathogenesis, murine models of 
experimental allergic airway disease are frequently employed (Kumar et al., 2016). It has been well established that initial sensitization at 8 weeks of age with the model antigen ovalbumin (OVA), followed by antigen challenge results in Th2-polarized airways disease, mimicking key essential clinical manifestations of human disease (von Garnier et al., 2007; Zosky et al., 2008). While 8-week-old sensitization models have provided significant advances in our understanding of asthmatic disease pathogenesis, they are not the best representative model for early life sensitization as mice attain sexual maturity at 8-12 weeks of age (Dutta and Sengupta, 2016). To address this age-dependent issue associated with murine models of allergic airway disease, this protocol sensitizes Th2-bias BALB/c mice during the early post-weanling period, paralleling that of early human childhood (Dutta and Sengupta, 2016). In brief, juvenile BALB/c mice are intraperitoneally sensitized to OVA at 21 and 35 days of age, followed by 3 consecutive OVA aerosol challenges on days $42-44$ of age, with autopsy $24 \mathrm{~h}$ post final aerosol.

\section{Materials and Reagents}

1. $1.5 \mathrm{ml}$ screw cap micro tube (SARSTEDT, catalog number: 72.703 .600 )

2. $5 \mathrm{ml}$ screw cap tube (SARSTEDT, catalog number: 60.9921.524)

3. $25 \mathrm{ml}$ screw cap tube (SARSTEDT, catalog number: 60.9922 .243 )

4. $27 \mathrm{G} \times 1 / 2 " 1 \mathrm{ml}$ Insulin syringe (Terumo, catalog number: SS*10M2713A)

5. Aluminum foil

6. $500 \mathrm{ml}$ Bottle Top Filter, $0.2 \mu \mathrm{m}$ pore size (Thermo Fisher Scientific, Nalgene ${ }^{\circledR}$ Rapid-Flow $^{\mathrm{TM}}$, catalog number: 595-4520)

7. $50 \mathrm{ml}$ serological pipette (SARSTEDT, catalog number: 86.1256.001)

8. 21-day-old BALB/c mice (Animal Resource Centre, Murdoch, Australia) Notes:

a. All mice were fed an OVA free diet.

b. Both male and female mice were used.

c. $n \geq 6$ mice per experiment.

9. Ovalbumin lyophilized powder (Sigma-Aldrich, catalog number: $A 5503$, store at $4{ }^{\circ} \mathrm{C}$ )

10. Aluminum hydroxide (SERVA, catalog number: 12261.02, store at room temperature in the dark)

11. Sterile Water for Irrigation (Baxter, catalog number: $2 \mathrm{~F} 7113$, store at room temperature)

12. Sodium chloride ( $\mathrm{NaCl}$ ) (Rowe Scientific, catalog number: CS10363)

13. Potassium chloride $(\mathrm{KCl})$ (Rowe Scientific, catalog number: $\mathrm{CP} 2600)$

14. Sodium phosphate dibasic anhydrous $\left(\mathrm{Na}_{2} \mathrm{HPO}_{4}\right)$ (Sigma-Aldrich, catalog number: RES20908A704X)

15. Potassium phosphate monobasic anhydrous $\left(\mathrm{KH}_{2} \mathrm{PO}_{4}\right)$ (Amresco, catalog number: 97062-350)

16. Hydrochloric acid $(\mathrm{HCl})$ (Sigma-Aldrich, catalog number: 320331-500ML)

17. Sterile phosphate buffered saline (PBS) (see Recipes)

18. $1 \mathrm{mg} / \mathrm{ml}$ ovalbumin stock solution (see Recipes) 
19. $10 \mathrm{mg} / \mathrm{ml}$ ovalbumin stock solution (see Recipes)

20. Ovalbumin-aluminum hydroxide (OVA-Alum) preparation for one mouse (see Recipes)

\section{Equipment}

1. Housing cages (Tecniplast, GM500)

2. $500 \mathrm{ml}$ measuring cylinder (Rowe Scientific, catalog number: GC1276)

3. $100 \mathrm{ml}$ Schott bottle (Sigma-Aldrich, Duran ${ }^{\circledR}$, catalog number: Z305170)

4. $500 \mathrm{ml}$ Schott bottle (Sigma-Aldrich, Duran ${ }^{\circledR}$, catalog number: Z305197)

5. $5,000 \mathrm{ml}$ Schott bottle (Sigma-Aldrich, Duran ${ }^{\circledR}$, catalog number: Z305227)

6. $5,000 \mathrm{ml}$ volumetric flask (Sigma-Aldrich, Duran ${ }^{\circledR}$, catalog number: 246787355 )

7. S1 Pipet Filler (Thermo Fisher Scientific, Thermo Scientific ${ }^{\top M}$, catalog number: 9521)

8. Rotary suspension mixer (Ratek, catalog number: RSM7DC)

9. Ultrasonic nebulizer (DeVilbiss Healthcare, UltraNeb, catalog number: U3000)

10. $25 \mathrm{~cm} \times 40 \mathrm{~cm}$ plexiglass aerosol chamber (AFM Plastics)

11. $-20^{\circ} \mathrm{C}$ freezer

\section{Software}

1. GraphPad Prism (GraphPad software, version 7.0a)

\section{Procedure}

A. Intraperitoneal sensitization of 21-day-old BALB/c mice (Figure 1)

1. Draw up $200 \mu \mathrm{l}$ of the OVA-Alum preparation using a $27 \mathrm{G} \times 1 / 2 " 1 \mathrm{ml}$ Insulin syringe.

2. Scruff mouse and hold on a 45-degree downwards angle with the head away from you.

Note: The holding technique used for intraperitoneal injections should adhere to independent in-house procedures.

3. Slowly inject the entire $200 \mu$ I OVA-Alum preparation intraperitoneally (i.p).

Notes:

a. Control mice received sham injection of $200 \mu l$ PBS.

b. Always use a new sterile syringe for each intraperitoneal injection.

4. Monitor mice for 3 days post-sensitization or as per individual in-house ethics requirements.

Note: OVA-sensitized mice are to be housed separately to control mice.

B. Intraperitoneal booster injection of 35-day-old mice (Figure 1)

1. Repeat Procedure $A$ at 35 days of age.

2. Monitor mice for 3 days post-sensitization or as per individual in-house ethics requirements. 
C. Ovalbumin aerosol challenge of 42-day-old sensitized mice (Figure 1)

1. Place sensitized mice in the plexiglass aerosol chamber connected to the ultrasonic nebulizer at a stock density of $\leq 10$.

Note: Do not overcrowd the plexiglass aerosol chamber. This ensures all mice receive an equivalent OVA aerosol dose.

2. Add $1 \times 25 \mathrm{ml}$ aliquot of $10 \mathrm{mg} / \mathrm{ml}$ OVA solution to the ultrasonic nebulizer.

Note: Control mice received PBS aerosol challenge.

3. Turn the ultrasonic nebulizer on with the following settings:
a. Cloud setting: 4
b. Fan setting: 3
c. Run time: 30 min

4. Following the $30 \mathrm{~min} 10 \mathrm{mg} / \mathrm{ml}$ OVA aerosol challenge, return the mice to their housing cages.

5. Repeat OVA aerosol challenge on Days 43 and 44 of age using freshly defrosted $10 \mathrm{mg} / \mathrm{ml}$ OVA solution aliquots.

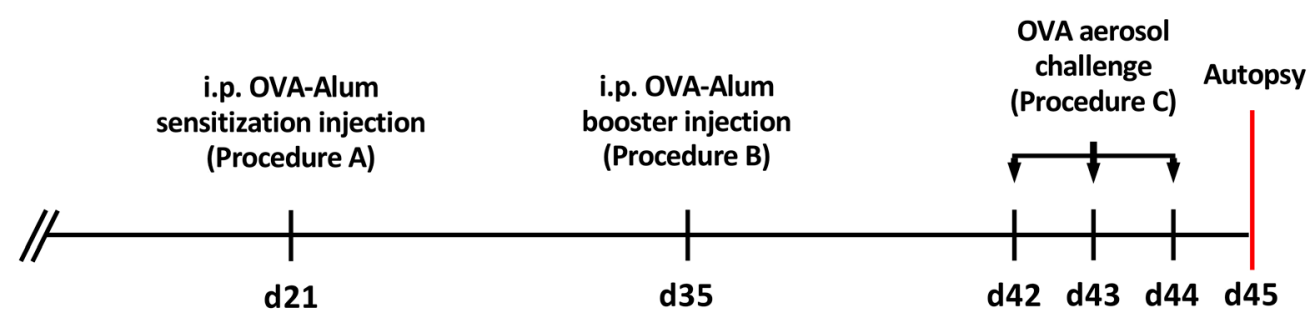

Figure 1. Timeline of intraperitoneal OVA-Alum injections and OVA aerosol challenges

\section{Data analysis}

As detailed in the original research article (Mincham et al., 2018), successful early life ovalbumin sensitization and aerosol challenge is clinically demonstrable by elevated levels of OVA-specific serum immunoglobulin $E$ as determined by passive cutaneous anaphylaxis assay (Figure $1 \mathrm{~A}$ in the original article), enhanced infiltration of inflammatory cell populations to the airways encompassing eosinophils, neutrophils, and lymphocytes (Figure 1B in the original article) and airways hyperresponsiveness following methacholine challenge (Figure $1 \mathrm{C}$ in the original article). Successful early life ovalbumin sensitization and aerosol challenge is also accompanied by elevated levels of Th2-associated cytokines interleukin (IL)-5 in the lung (Figure 2A) and IL-4 and IL-5 in the airway draining lymph nodes (Figure 2B). 


\section{Representative data:}

A

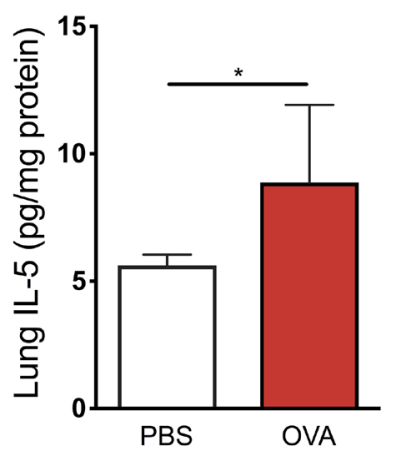

B

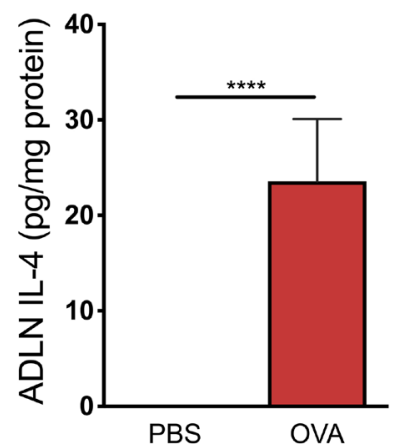

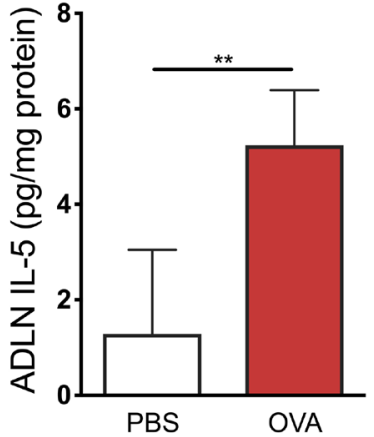

Figure 2. Elevated Th2 cytokines following successful early life ovalbumin sensitization and aerosol challenge. A. Elevated levels of interleukin (IL)-5 in peripheral lung homogenates of early life OVA sensitized and aerosol challenged mice. B. Elevated levels of IL-4 and IL-5 in airway draining lymph node (ADLN) homogenates of early life OVA sensitized and aerosol challenged mice. Data shows mean \pm SEM of $n \geq 4$ independent experiments. Statistical significance was determined using Student's $t$-test and presented as ${ }^{*} P<0.05,{ }^{* *} P<0.01,{ }^{* \star * *} P$ $<0.0001$.

\section{$\underline{\text { Notes }}$}

1. Be gentle when adding OVA lyophilized power to sterile water for irrigation. Do not stir the solution to accelerate dissolving rate as this will cause the OVA to denature.

2. Gently pour the OVA solution when filtering. Rapid pouring will cause the OVA to denature.

3. All mice were autopsied $24 \mathrm{~h}$ after the final OVA aerosol challenge in the original research article (Mincham et al., 2018). However, this protocol could be used to assess allergic airway inflammation at any time point after the final OVA aerosol challenge.

\section{Recipes}

1. Sterile Phosphate buffered saline (to make $5 \mathrm{~L}$ )

a. Dissolve $43.9 \mathrm{~g} \mathrm{NaCl}, 1 \mathrm{~g} \mathrm{KCl}, 5.75 \mathrm{~g} \mathrm{Na}_{2} \mathrm{HPO}_{4}, 1 \mathrm{~g} \mathrm{KH}_{2} \mathrm{PO}_{4}$ in $5,000 \mathrm{ml}$ sterile water in a $5,000 \mathrm{ml}$ volumetric flask and add $0.2 \mathrm{ml} \mathrm{HCl}$

b. Once dissolved, filter PBS solution into a sterile $5,000 \mathrm{ml}$ Schott bottle using a $500 \mathrm{ml}$ bottle top filter

c. Aliquot the sterile PBS solution into $500 \mathrm{ml}$ aliquots

2. $1 \mathrm{mg} / \mathrm{ml}$ ovalbumin stock solution

a. Dissolve $0.1 \mathrm{~g}$ OVA lyophilized powder in $100 \mathrm{ml}$ sterile water for irrigation by placing lyophilized OVA powder on the water surface and allow to slowly dissolve at room 
temperature. Do not stir the solution (Note 1)

b. Once dissolved, filter the $1 \mathrm{mg} / \mathrm{ml}$ OVA solution into a sterile $100 \mathrm{ml}$ Schott bottle using a $500 \mathrm{ml}$ bottle top filter (Note 2)

c. Aliquot the sterile $1 \mathrm{mg} / \mathrm{ml}$ OVA solution into $1 \mathrm{ml}$ aliquots $(1.5 \mathrm{ml}$ screw cap micro tubes)

d. Store at $-20^{\circ} \mathrm{C}$

3. $10 \mathrm{mg} / \mathrm{ml}$ ovalbumin stock solution

a. Dissolve $5 \mathrm{~g}$ OVA lyophilized powder in $500 \mathrm{ml}$ sterile water for irrigation by placing lyophilized OVA powder on the water surface and allow to slowly dissolve at room temperature. Do not stir the solution (Note 1)

b. Once dissolved, filter the $10 \mathrm{mg} / \mathrm{ml}$ OVA solution into a sterile $500 \mathrm{ml}$ Schott bottle using a $500 \mathrm{ml}$ bottle top filter (Note 2)

c. Aliquot the sterile $10 \mathrm{mg} / \mathrm{ml}$ OVA solution into $25 \mathrm{ml}$ aliquots using a $50 \mathrm{ml}$ serological pipette and S1 Pipet Filler ( $25 \mathrm{ml}$ screw cap tubes)

d. Store at $-20^{\circ} \mathrm{C}$

4. Ovalbumin-aluminum hydroxide (OVA-Alum) preparation for one mouse

a. For each mouse, emulsify $20 \mu \mathrm{l}$ of $1 \mathrm{mg} / \mathrm{ml}$ OVA solution in $180 \mu \mathrm{l}$ of aluminum hydroxide to give a final concentration of $20 \mu \mathrm{g}$ OVA and $1.3 \mathrm{mg}$ aluminum hydroxide in a total volume of $200 \mu \mathrm{l}$. Increase as necessary for the total number of mice to be sensitized

b. Wrap the tube ( $5 \mathrm{ml} \mathrm{screw}$ cap tube) containing the OVA-Alum preparation in aluminum foil and spin for $1 \mathrm{~h}$ at $20 \mathrm{rpm}$ using a rotary suspension mixer

\section{Acknowledgments}

The authors would like to acknowledge the animal technicians at the Telethon Kids Institute Bioresources facility. The original research article (Mincham et al., 2018) utilizing this protocol was funded by the National Health and Medical Research Council of Australia.

\section{Competing interests}

The authors declare no financial or non-financial competing interests related to this work.

\section{Ethics}

All animal experiments relating to this protocol were formally approved by the Telethon Kids Institute Animal Ethics Committee, which operates under guidelines developed by the National Health and Medical Research Council of Australia for the care and use of animals in scientific research. 


\section{References}

1. Bousquet, J., Jeffery, P. K., Busse, W. W., Johnson, M. and Vignola, A. M. (2000). Asthma. From bronchoconstriction to airways inflammation and remodeling. Am J Respir Crit Care Med 161(5): 1720-1745.

2. Dutta, S. and Sengupta, P. (2016). Men and mice: relating their ages. Life Sci 152: 244-248.

3. Holgate, S. T. (2008). Pathogenesis of asthma. Clin Exp Allergy 38(6): 872-897.

4. Holt, P. G., Upham, J. W. and Sly, P. D. (2005). Contemporaneous maturation of immunologic and respiratory functions during early childhood: implications for development of asthma prevention strategies. J Allergy Clin Immunol 116(1): 16-24; quiz 25.

5. Jackson, D. J., Gern, J. E. and Lemanske, R. F., Jr. (2016). The contributions of allergic sensitization and respiratory pathogens to asthma inception. J Allergy Clin Immunol 137(3): 659665; quiz 666.

6. Johnston, S. L., Pattemore, P. K., Sanderson, G., Smith, S., Lampe, F., Josephs, L., Symington, P., Toole, S. O., Myint, S. H., Tyrrell, D. A. J. and Holgate, S. T. (1995). Community study of role of viral infections in exacerbations of asthma in 9-11 year old children. BMJ 310(6989): 1225-1229.

7. Kumar, R. K., Herbert, C. and Foster, P. S. (2016). Mouse models of acute exacerbations of allergic asthma. Respirology 21(5): 842-849.

8. Masoli, M., Fabian, D., Holt, S., Beasley, R. and Global Initiative for Asthma, P. (2004). The global burden of asthma: executive summary of the GINA Dissemination Committee report. Allergy 59(5): 469-478.

9. Mincham, K. T., Scott, N. M., Lauzon-Joset, J. F., Leffler, J., Larcombe, A. N., Stumbles, P. A., Robertson, S. A., Pasquali, C., Holt, P. G. and Strickland, D. H. (2018). Transplacental immune modulation with a bacterial-derived agent protects against allergic airway inflammation. $J$ Clin Invest 128(11): 4856-4869.

10. Soriano, J. B., Abajobir, A. A., Abate, K. H., Abera, S. F., Agrawal, A., Ahmed, M. B., Aichour, A. N., Aichour, I., Aichour, M. T. E., Alam, K., Alam, N., Alkaabi, J. M., Al-Maskari, F., Alvis-Guzman, N., Amberbir, A., Amoako, Y. A., Ansha, M. G., Antó, J. M., Asayesh, H., Atey, T. M., Avokpaho, E. F. G. A., Barac, A., Basu, S., Bedi, N., Bensenor, I. M., Berhane, A., Beyene, A. S., Bhutta, Z. A., Biryukov, S., Boneya, D. J., Brauer, M., Carpenter, D. O., Casey, D., Christopher, D. J., Dandona, L., Dandona, R., Dharmaratne, S. D., Do, H. P., Fischer, F., Gebrehiwot, T. T., Geleto, A., Ghoshal, A. G., Gillum, R. F., Ginawi, I. A. M., Gupta, V., Hay, S. I., Hedayati, M. T., Horita, N., Hosgood, H. D., Jakovljevic, M. B., James, S. L., Jonas, J. B., Kasaeian, A., Khader, Y. S., Khalil, I. A., Khan, E. A., Khang, Y.-H., Khubchandani, J., Knibbs, L. D., Kosen, S., Koul, P. A., Kumar, G. A., Leshargie, C. T., Liang, X., El Razek, H. M. A., Majeed, A., Malta, D. C., Manhertz, T., Marquez, N., Mehari, A., Mensah, G. A., Miller, T. R., Mohammad, K. A., Mohammed, K. E., Mohammed, S., Mokdad, A. H., Naghavi, M., Nguyen, C. T., Nguyen, G., Le Nguyen, Q., Nguyen, T. H., Ningrum, D. N. A., Nong, V. M., Obi, J. I., Odeyemi, Y. E., Ogbo, F. A., Oren, E., 
Pa, M., Park, E.-K., Patton, G. C., Paulson, K., Qorbani, M., Quansah, R., Rafay, A., Rahman, M. H. U., Rai, R. K., Rawaf, S., Reinig, N., Safiri, S., Sarmiento-Suarez, R., Sartorius, B., Savic, M., Sawhney, M., Shigematsu, M., Smith, M., Tadese, F., Thurston, G. D., Topor-Madry, R., Tran, B. X., Ukwaja, K. N., van Boven, J. F. M., Vlassov, V. V., Vollset, S. E., Wan, X., Werdecker, A., Hanson, S. W., Yano, Y., Yimam, H. H., Yonemoto, N., Yu, C., Zaidi, Z., El Sayed Zaki, M., Lopez, A. D., Murray, C. J. L. and Vos, T. (2017). Global, regional, and national deaths, prevalence, disability-adjusted life years, and years lived with disability for chronic obstructive pulmonary disease and asthma, 1990-2015: a systematic analysis for the Global Burden of Disease Study 2015. Lancet Respir Med 5(9): 691-706.

11. von Garnier, C., Wikstrom, M. E., Zosky, G., Turner, D. J., Sly, P. D., Smith, M., Thomas, J. A., Judd, S. R., Strickland, D. H., Holt, P. G. and Stumbles, P. A. (2007). Allergic airways disease develops after an increase in allergen capture and processing in the airway mucosa. $J$ Immunol 179(9): 5748-5759.

12. Zosky, G. R., Larcombe, A. N., White, O. J., Burchell, J. T., Janosi, T. Z., Hantos, Z., Holt, P. G., Sly, P. D. and Turner, D. J. (2008). Ovalbumin-sensitized mice are good models for airway hyperresponsiveness but not acute physiological responses to allergen inhalation. Clin Exp Allergy 38(5): 829-838. 